\title{
Virtual Work and Work-Life Balance for Managers
}

\author{
Gudbjörg Linda Rafnsdóttir ${ }^{1}$ \& Arnaldur S. Stefánsson ${ }^{2}$ \\ ${ }^{1}$ Department of Sociology, University of Iceland, Iceland \\ ${ }^{2}$ Department of Economics, Uppsala University, Sweden \\ Correspondence: Professor G. Linda Rafnsdóttir, Department of Sociology, Faculty of Social and Human \\ Sciences, University of Iceland, Oddi, Sturlugata, IS 101 Reykjavík, Iceland. E-mail: glr@hi.is
}

Received: September 15, 2014

Accepted: September 30, 2014

Online Published: October 22, 2014

doi:10.5539/ijbm.v9n11p1

URL: http://dx.doi.org/10.5539/ijbm.v9n11p1

\begin{abstract}
The overall objective of the study is to analyze whether the possibility of working virtually generates work-family balance and well-being for managers. More specifically, we ask: Does virtual technology make the reconciliation of work and family life easier or more complicated? Does it prolong or shorten the workday?

Are those who have a positive attitude toward the technology more likely to experience well-being than others?

An online questionnaire was sent to CEOs and vice CEOs in the 500 largest companies and to heads of the largest governmental institutions in Iceland. The response rate was $50 \%$. The method of analysis is Fisher's exact test, binomial test for goodness-of-fit, and logit regressions.

The majority of managers say that virtual technology prolongs the workday and around half of them view the reconciliation of work and family life as becoming more complicated. However, they say the reconciliation of work and family is becoming easier. Men who say that virtual technology decreases their well-being are more likely than other men to experience stress, exhaustion, and to find their job demanding. We do not see the same connection among women.

It is important that human resource managers and those who are responsible for the work environment and occupational health define a policy about virtual work in order to prevent excessively high workloads and negative effects from work to family.
\end{abstract}

Keywords: gender, managers, virtual work, well-being, work-life balance

\section{Introduction}

Since the global economic crisis in 2008, lack of gender diversity in business leadership has been in the spotlight in Iceland and elsewhere in Europe (Rafnsdóttir et al., 2014). As an example, the European Parliament states that the present dearth of women in managerial positions in business in general is unacceptable (European Parliament, 2011). As a consequence, the European Commission proposed a directive on "Improving the gender balance among non-executive directors of companies listed on stock exchanges and related measures" (Note 1).

Different reasons have been put forward to explain what hinders women from being part of the top leadership in business (Saebjornsdottir \& Edvardsson, 2012). The demand for long and inflexible working hours is often seen as one of the primary hindrances for women entering these positions, even in countries with well-developed gender equality regimes like Iceland and the other Nordic countries (Rafnsdóttir, 2011; Lyon \& Woodward, 2004). Blair-Loy (2001), who researched work-life balance among managers in the USA, concludes that even if family-friendly workplaces have increased in number and the workplace culture increasingly takes into account work-life balance, the family is still a burden for women rather than men in leading positions. Thus, women in managerial positions have more daily responsibility for family and children than their male counterparts. This is in line with Rodriguez (2011) who notes that female managers still meet hindrances related to family responsibilities that their male counterparts do not face. In a recent study, Heikkinen, Lämsä, \& Hiillos (2013) show that female managers in Finland in general do not challenge the traditional gender order in their families. Instead, they produce themselves as bravely taking on both the conventional private feminine role and the public masculine role. In this way, they manage both their career and family without "rocking the boat". In a longitudinal Swedish study, it was found that women experience conflict between work and family life more often than men. However, both men's and women's health was negatively affected by work-life conflict as it was 
associated with an increased risk of emotional exhaustion among both genders, increased risk for poor self-rated health among women, and problem drinking among men (Leineweber, Baltzer, Hanson \& Westerlund, 2012).

\section{Digital Technology and Work-Life Balance}

At the end of the 1990s, when digital technology had developed in such a way that working online was more common, the fixed boundaries between home and work were gradually eroded. Workplaces transformed in many ways and the location of existing work changed as home-based teleworking was made possible. With workers increasingly paid and managed by results and requirements for flexibility, the hours spent formally working were less likely to be counted (Huws, 2013). In addition, to improve work-life balance, virtual reality was seen as a new space for undermining old social relations, a place of freedom and liberation from conventional gender roles. "The virtuality of cyberspace is seen to spell the end of naturalized, biological embodiment as the basis for gender difference. ... Technology itself is seen as liberating women" (Wajcman, 2004, p. 7).This is partly in line with Heijstraand Rafnsdóttir (2010), who show that female academics are more likely to say that the Internet improves work-life balance than their male counterparts. Thus, digital technology can be useful for daily private routines as well as for work. Mobile phones give employees a sense of security, in that they are only a phone call away from their children or their elderly parents, etcetera. Furthermore, with the help of digital technology, they can stay in immediate interactive contact with family, friends, and workmates, whether they are in the office, at home, or abroad. However, these blurring boundaries between work and family and increasing flexibility in workalso make it difficult for employees to disengage themselves from work. In other words, the freer the work, the more difficult it is to become free from work. Kvande (2007) and Blair-Loy (2009) point out that the shift from standard to flexible working hours can lead to an endless flood of work, extensive working hours, and work-family conflict, especially in knowledge organizations. According to Rafnsdóttir and Heijstra (2013), flexibility has resulted in gendered time use and the reproduction of traditional power relations between women and men and gender segregated divisions in the home.

Due to these misleading results about work-life balance and virtual work, we support Huws' (2013) argument that many questions about the use of digital technology still remain to be answered. Our study aims to overcome this gap in knowledge by empirically studying how female and male managers in Iceland, the number one country in relation to gender equality in the world, experience digital technology in relation to work-life balance. The overall objective of the study is to analyze whether the possibility of working virtually generates work-family balance and well-being among managers. More specifically, we ask: Does virtual technology make the reconciliation of work and family life easier or more complicated? Does it prolong or shorten the workday? Are those who have a positive attitude toward the technology more likely to experience well-being than others? In our analyses, we take into account gender, age, marital status, children under 20 years old, and the age of the children.

A culture of long working hours prevails among managers, where overtime is an expected part of the working life. As managers also belong to the group of employees who work to a large part virtually (Note 2) part of their work moves to their home, especially during late evenings and weekends. Therefore, we aim to understand to what extent virtual work affects the boundaries between paid and unpaid work.

\section{The Icelandic Setting}

Iceland is an ideal place for these studies as in 2012, 96\% of households had an Internet connection, making Iceland number two in the world in regard to Internet users, next after the Falkland Islands (Global Internet users, 2012). Iceland is number three in Europe in regard to the amount of companies that provide the employees wireless internet access (Statistic Iceland, n.d.). In addition, 98\% of households have one or more mobile phones (Statistics Iceland, 2012). Icelanders also see themselves as a gender equal nation and Iceland has been rated number one on the Gender Gap Index since 2009 (The Global Gender Gap Report, 2013). Furthermore, the country has the highest female labor force participation rate, 84.8, among 25- to 64-year-olds in the OECD countries (2013), while the average number within the OECD is 67 (OECDStat. Extracts). Nevertheless, lack of gender balance among business leadership is a fact (Rafnsdóttir, 2011). Therefore, Iceland adopted a gender quota for corporate boards in 2010, which came into force in the fall of 2013. In 2011, 51\% of men in Iceland and $72 \%$ of women supported the gender quota law, while only $4 \%$ of women and $11 \%$ of men believed that the lack of gender diversity might be explained by the fact that managers' jobs are less suitable for women. On the other hand, $76 \%$ of women and $60 \%$ of men believed it can be explained by lack of work-life balance (Rafnsdóttir, 2011).

In light of this, we see Iceland as a favorable country for studying virtual work and work-life balance among female and male managers. 


\section{Method}

An online questionnaire was conducted in 2010. Survey Monkey was used to send the questionnaire to CEOs/vice CEOs in the 500 largest companies in Iceland and to heads of the largest governmental institutions in Iceland. Partly due to the economic collapse in 2008, some of the companies on the list had closed down; others had moved abroad or merged with other companies. Thus, we were not able to contact all the individuals and attain their e-mail addresses. In the end, there were 447 (62 women, 385 men) CEOs from private companies and 169 (100 women, 69 men) vice CEOs. In addition, there were 218 (65 women, 153 men) heads of public institutions. There were 47 inactive e-mail addresses. Accordingly, 784 individuals received the questionnaire ( 215 women, 569 men). Of these, 389 replied to the questions, so the response rate was $50 \%$. However, 52 out of these 389 left some unanswered questions.

There were three main questions:

1). Does virtual technology make the reconciliation of work and family life easier or more complicated? The following two statements are used to capture this technology/family question (TFAM):

1a. TFAM ${ }_{1}$ Virtual technology makes the reconciliation of work and family life easier as it enables me to work at home or on my vacation.

1 if agrees, 0 if disagrees

1b. TFAM $\mathrm{M}_{2}$ irtual technology makes the reconciliation of work and family life more complicated as it is more difficult to be off from work, even on my vacation.

1 if disagrees, 0 if agrees

2). Does virtual technology prolong or shorten the workday? The following three statements are used to capture this technology/hours question (THRS):

2a.THRS ${ }_{1}$ Virtual technology prolongs the workday because it is difficult not to continue to work when the formal workday is over.

1 if disagrees, 0 if agrees

2b. THRS ${ }_{2}$ Virtual technology shortens the workday because it allows me to use all dead moments to work wherever I am.

1 if agrees, 0 if disagrees

2c. THRS ${ }_{3}$ Virtual technology shortens the workday because it is easier for me to work fast when I am not at the workplace.

1 if agrees, 0 if disagrees

3). Are those who have a positive attitude toward the technology more likely to experience well-being than others? The following two statements are used to capture this technology/well-being question (TWB):

3a. $\mathrm{TWB}_{1}$ : The technology increases my well-being because I can partly work from home instead of being bound to the workplace.

1 if agrees, 0 if disagrees

3b. $\mathrm{TWB}_{2}$ : The technology decreases my well-being because it prevents me actually feeling being off work.

1 if disagrees, 0 if agrees

The following three questions are also used to capture this well-being issue (WB):

STRESS: Have you recently experienced stress?

0 if little or none, 1 if much

EXHWD: Are you mentally exhausted after the working day?

0 if never/seldom/sometimes, 1 if often/always

JOBDEM: How mentally demanding or easy do you find your own job?

0 if easy, 1 if difficult

We take into account gender, age, marital status, children under 20 years old, and the age of the children.

FEM: 0 if male, 1 if female

AGE: 0 if younger than 40 years old, 1 if 40 years or older 
MAR: 0 if single, divorced, or widowed, 1 if in a relationship (married or cohabiting)

CHI: 0 if no child, 1 if at least one child (20 years old or younger) living in the household

YOUNG: 0 if at least one child eight years or younger is living in the household, 1 if at least one child eight years old or younger living in the household

$\mathrm{HRS}_{\mathrm{m}}: 1$ if spending 50 to 59 hours a week on paid work

$\mathrm{HRS}_{1}: 1$ if spending 60 hours a week or more on paid work

HRSp: 1 if partner spends 40 hours a week or more on salaried work

The variables TFAM1, TFAM2, THRS1, THRS2, THRS3, TWB1, and TWB2 are all constructed such that 0 represents what we see as a negative attitude toward technology and 1 represents what we see as a positive attitude toward technology. Therefore, in the regression tables shown below, a positive coefficient by a variable indicates that the variable increases the probability of showing a positive attitude toward technology. Furthermore, STRESS, EXHWD, and JOBDEM are constructed such that 0 represents well-being and 1 represents lack of well-being.

Fisher's exact tests are used to see if the probability of individuals agreeing with the questions above is significantly different by gender. For each question, the null hypothesis is that the probability of men and women agreeing is the same. The p-value from Fisher's exact tests is the probability of obtaining the observed data if the probability of men and women agreeing with the questions is the same. Therefore, we reject the null hypothesis and say that the probability of men and women agreeing is different if the p-value is significantly low.

We also carry out an exact binomial test for goodness-of-fit to see if the probability of individuals agreeing with the questions is significantly different from 0.5 . Again, the p-value from the exact binomial test is the probability of obtaining the observed data if the null hypothesis is true, where the null hypothesis is that the probability of agreeing (or disagreeing) is 0.5 . If the p-value is lower than 0.05 , the relevant proportions are marked with asterisks: ${ }^{*} p<0.05,{ }^{*} p<0.01, * * * p<0.001$.

Finally, logistic regressions are carried out. It can be used to analyze whether certain factors significantly affect the probability of an event taking place. However, we can only infer whether that variable increases or decreases the probability of an event taking place but not the scale. If the sign of the coefficient is positive, then the variable increases the probability. On the other hand, if the sign of the coefficient is negative, it decreases the probability.

Table 1. Crude tables and binomial estimations

\begin{tabular}{|c|c|c|c|}
\hline & $\underline{\text { Male }}$ & Female & $\underline{\text { Total }}$ \\
\hline \multicolumn{4}{|l|}{$\underline{\mathrm{AGE}}$} \\
\hline Younger than 40 years old & $13 \%(31)$ & $19 \%(18)$ & $15 \%(49)$ \\
\hline 40 years old and older & $87 \%(209)$ & $81 \%(79)$ & $85 \%(288)$ \\
\hline \multicolumn{4}{|l|}{$\underline{\text { MAR }}$} \\
\hline Single/Divorced & $3 \%(6)$ & $16 \%(16)$ & $7 \%(22)$ \\
\hline Relationship & $97 \%(234)$ & $84 \%(81)$ & $93 \%(315)$ \\
\hline \multicolumn{4}{|l|}{$\underline{\mathrm{CHI}}$} \\
\hline None & $34 \%(81)$ & $26 \%(25)$ & $31 \%(106)$ \\
\hline One or more & $66 \%(159)$ & $74 \%(72)$ & $69 \%(231)$ \\
\hline \multicolumn{4}{|l|}{ YOUNG } \\
\hline Other & $75 \%(179)$ & $64 \%(62)$ & $72 \%(241)$ \\
\hline Youngest child 0 to 8 years old & $25 \%(61)$ & $36 \%(35)$ & $28 \%(96)$ \\
\hline \multicolumn{4}{|l|}{$\underline{\mathrm{HRS}}_{\underline{\mathrm{m}}}$} \\
\hline Other & $52 \%(126)$ & $73 \%(71)$ & $58 \%(197)$ \\
\hline Working 50 to $59 \mathrm{hrs}$ & $48 \%(114)$ & $27 \%(26)$ & $42 \%(140)$ \\
\hline \multicolumn{4}{|l|}{$\underline{\mathrm{HRS}_{\underline{h}}}$} \\
\hline Other & $73 \%(176)$ & $82 \%(80)$ & $76 \%(256)$ \\
\hline Working $60 \mathrm{hrs}$ or more & $27 \%(64)$ & $18 \%(17)$ & $24 \%(81)$ \\
\hline \multicolumn{4}{|l|}{$\underline{H R S}_{\underline{p}}$} \\
\hline Less than $40 \mathrm{hrs} /$ Does not apply & $56 \%(130)$ & $7 \%(6)$ & $43 \%(136)$ \\
\hline $40 \mathrm{hrs}$ or more & $44 \%(104)$ & $93 \%(75)$ & $57 \%(179)$ \\
\hline
\end{tabular}




\begin{tabular}{lccc}
\hline$\underline{\text { STRESS }}$ & & & \\
Little or none & $66 \%(159)$ & $59 \%(57)$ & $64 \%(216)$ \\
Much & $34 \%(81)$ & $41 \%(40)$ & $36 \%(121)$ \\
$\underline{\text { JOBDEM }}$ & & & \\
Easy & $34 \%(82)$ & $33 \%(32)$ & $34 \%(114)$ \\
Difficult & $66 \%(158)$ & $67 \%(65)$ & $66 \%(223)$ \\
EXHWD & & & \\
Never/Seldom/Sometimes & $24 \%(58)$ & $22 \%(21)$ & $23 \%(79)$ \\
Often/Always & $76 \%(182)$ & $78 \%(76)$ & $77 \%(258)$ \\
\hline
\end{tabular}

Comment: The proportion within each group (male, female, and total) is shown as well as the number in parenthesis.

Table 1 shows the distribution of the data divided by male and female managers and the total.

As seen in Table 1, the majority of managers are 40 years and older, $93 \%$ are married or cohabiting, and $69 \%$ have one or more children, most of them older than eight years old. The majority $(66 \%)$ work 50 hours a week or more, and also the majority (57\%) have a partner who works 40 hours a week or more. The majority (69\%) have children, although the minority have children eight years or younger. About two-thirds (68\%) work 50 hours a week or more and only $7 \%$ of women have a partner who works less than 40 hours a week. This applies to $56 \%$ of men. Over one-third (36\%) feel much work stress, but the majority $(66 \%)$ feel that the job demands are difficult and they feel exhausted often or always (77\%) after the workday.

As top managers are more likely to be male than female, there are more men than women in our dataset. The are some gender differences in the data. Table 1 shows that being female is negatively correlated with being in a relationship and spending 50 hours a week or more on paid work. On the other hand, it is positively correlated with having a partner who spends 40 hours a week or more on paid work, having one or more children, having young children, and feeling stressed.

\section{Results}

The overall objective of the study is to analyze whether the possibility of working virtually generates work-family balance and well-being among managers. More specifically, we ask: Does virtual technology make the reconciliation of work and family life easier or more complicated? Does it prolong or shorten the workday? Are those who have a positive attitude toward the technology more likely to experience well-being than others? In our analyses, we take into account gender, age, marital status, children under 20 years old, and the age of the children.

\subsection{Work-Life Balance}

Table 2. Does technology make the reconciliation of work and family life easier?

\begin{tabular}{lllll}
\hline & ALL & MALE & FEMALE & Fisher \\
\hline TFAM1 & $0.81^{* * *}$ & $0.81^{* * *}$ & $0.80^{* * *}$ & 1.000 \\
TFAM2 & 0.45 & $0.42 *$ & 0.53 & 0.091 \\
$\mathrm{~N}$ & 337 & 240 & 97 & \\
\hline
\end{tabular}

Note. ${ }^{*} \mathrm{p}<0.05, * * \mathrm{p}<0.01, * * * \mathrm{p}<0.001$.

As shown in Table 2, the majority of male and female managers $(81 \%$ vs. $80 \%)$ say that virtual technology makes the reconciliation of work and family easier as it enables them to work at home or on their vacation (agree in TFAM1). However, only 45\% disagree with the statement that technology makes the reconciliation of work and family life more complicated as it is more difficult to be off from work, even on vacation (disagree in TFAM2). In other words, $47 \%$ of female managers and $58 \%$ of their male counterparts see the reconciliation of work and family life as becoming more complicated due to the above-mentioned factors, even if they say that the reconciliation of work and family becomes easier. 
Table 3. Logistic estimate for TFAM

\begin{tabular}{|c|c|c|c|c|c|c|}
\hline & \multicolumn{3}{|c|}{ TFAM1 } & \multicolumn{3}{|c|}{ TFAM2 } \\
\hline & $\begin{array}{l}\text { All } \\
(1) \\
\end{array}$ & $\begin{array}{l}\text { Male } \\
(2) \\
\end{array}$ & $\begin{array}{l}\text { Female } \\
\text { (3) }\end{array}$ & $\begin{array}{l}\text { All } \\
(4) \\
\end{array}$ & $\begin{array}{l}\text { Male } \\
(5) \\
\end{array}$ & $\begin{array}{l}\text { Female } \\
(6)\end{array}$ \\
\hline \multicolumn{7}{|l|}{ Demography: } \\
\hline FEM & 0.4 & & & -0.004 & & \\
\hline AGE & 0.05 & 0.3 & -1.1 & -0.4 & -0.09 & -1 \\
\hline MAR & 1.5 & Omitted & -0.01 & $-1.1^{*}$ & -0.5 & -0.4 \\
\hline $\mathrm{CHI}$ & 0.5 & -0.3 & -0.9 & -0.4 & -0.5 & 0.1 \\
\hline YOUNG & 0.7 & 0.3 & $1.5^{*}$ & 0.05 & 0.3 & -0.5 \\
\hline \multicolumn{7}{|l|}{ Hours: } \\
\hline HRSm & 0.1 & 0.06 & 0.5 & -0.5 & -0.3 & $-1.0 *$ \\
\hline HRSh & 0.3 & 0.2 & 0.7 & $-0.9 * *$ & -0.7 & $-1.5^{*}$ \\
\hline HRSp & $0.7^{*}$ & $0.7^{*}$ & -0.6 & 0.3 & 0.5 & -0.9 \\
\hline Constant & $2.6^{* *}$ & 0.9 & $3.0^{*}$ & $1.6^{*}$ & 0.6 & $2.6^{* *}$ \\
\hline Log-likelihood & 159.8 & -113 & -42.9 & -222.3 & -159.3 & -59.4 \\
\hline Likelihood ratio $\chi^{2}$ & 10.9 & 5.9 & 10.2 & 19.2 & 8 & 15.4 \\
\hline p-value & 0.2 & 0.4 & 0.2 & 0.01 & 0.3 & 0.03 \\
\hline $\mathrm{N}$ & 337 & 234 & 97 & 337 & 240 & 97 \\
\hline
\end{tabular}

Note. ${ }^{*} \mathrm{p}<0.05, * * \mathrm{p}<0.01, * * * \mathrm{p}<0.001$.

In Table 3, we use logistic regression to analyze if managers' age, marital status, number and age of children, their own working hours, and the working hours of their spouses significantly affect the probability of the outcome for both genders. When looking at the first statement, "Technology makes the reconciliation of work and family life easier as it enables me to work at home or on my vacation" (TFAM1), we see that the working hours of partners (HRSp) for males and the presence of at least one child eight years or younger (YOUNG) for women increase the probability of supporting the statement. This means that male managers who have a partner who works 40 hours a week or more are more likely than other men to say that the work-life balance improves due to virtual technology as they can work at home or on vacation. This is not significant for women. In contrast to male managers, almost all female managers in our data have a spouse who works full-time.

Table 3 also shows the probability of managers disagreeing with the statement, "Virtual technology makes the reconciliation of work and family life more complicated as it is more difficult to be off from work, even on my vacation" (TFAM2). Only two coefficients are significant. First, both female and male managers in a relationship (MAR) are more likely to disagree with the statement than single ones. Thus, they are more likely to see virtual work as accessible in relation to the statement. This is also the case for female managers working 60 hours or more (HRSh). They were more likely than other women to see virtual work as uncomplicated.

\subsection{Virtual Technology and the Length of the Workday}

Instead of analyzing the work-life balance as tables 2 and 3, the next two tables show questions about the length of the workday.

Table 4. Does technology prolong the workday?

\begin{tabular}{rlllll} 
& & ALL & MALE & FEMALE & Fisher \\
\cline { 2 - 6 } THRS1 & 0.44 & 0.45 & 0.43 & 0.904 \\
THRS2 & 0.45 & 0.46 & 0.41 & 0.469 \\
THRS3 & 0.43 & 0.44 & 0.41 & 0.716 \\
Note $* \mathrm{p}<0.05, * * \mathrm{p}<0.01, * * * \mathrm{p}<0.001$. & 337 & 240 & 97 & \\
\hline
\end{tabular}

Table 4 shows that the minority (44\%) of managers disagree with the statement, "The technology prolongs the workday because it is difficult not to continue to work when the formal workday is over" (THRS1). In other words, $56 \%$ of managers say the technology prolongs the workday as the work moves from the office to the 
home. Also the minority (45\%) say the technology shortens the workday because it allows them to use all dead moments to work wherever they are (THRS2). The minority (43\%) say the technology shortens the workday because it is easier to work fast when not at the workplace (THRS3). The gender difference is not statistically significant.

Table 5. Logit estimate for THRS

\begin{tabular}{|c|c|c|c|c|c|c|c|c|c|}
\hline & \multicolumn{3}{|l|}{ THRS1 } & \multicolumn{3}{|c|}{ THRS2 } & \multicolumn{3}{|l|}{ THRS3 } \\
\hline & $\begin{array}{l}\text { All } \\
(1)\end{array}$ & $\begin{array}{l}\text { Male } \\
(2)\end{array}$ & $\begin{array}{l}\text { Female } \\
(3)\end{array}$ & $\begin{array}{l}\text { All } \\
(4)\end{array}$ & $\begin{array}{l}\text { Male } \\
(5) \\
\end{array}$ & $\begin{array}{l}\text { Female } \\
(6)\end{array}$ & $\begin{array}{l}\text { All } \\
(7)\end{array}$ & $\begin{array}{l}\text { Male } \\
(8) \\
\end{array}$ & $\begin{array}{l}\text { Female } \\
(9)\end{array}$ \\
\hline \multicolumn{10}{|l|}{ Demography: } \\
\hline FEM & -0.6 & & & -0.3 & & & -0.4 & & \\
\hline AGE & -0.4 & -0.2 & -0.7 & 0.3 & $1.1^{*}$ & -0.8 & 0.4 & 0.9 & -0.5 \\
\hline MAR & -0.2 & -0.2 & 0.6 & -0.5 & 0.3 & -0.7 & $-1.2^{*}$ & -0.8 & -0.3 \\
\hline CHI & -0.3 & -0.2 & -0.5 & -0.3 & -0.3 & -0.2 & -0.2 & -0.1 & -0.4 \\
\hline YOUNG & -0.2 & 0.02 & -0.7 & 0.5 & $0.9^{*}$ & -0.3 & 0.6 & $0.9^{*}$ & 0.3 \\
\hline \multicolumn{10}{|l|}{ Hours: } \\
\hline HRSm & $-1.1 * * *$ & $-1.2 * * *$ & -0.8 & -0.3 & -0.4 & 0.05 & 0.09 & -0.1 & 0.6 \\
\hline HRSh & $-1.4 * * *$ & $-1.4^{* * *}$ & $-1.9 * *$ & -0.2 & 0.005 & -0.9 & 0.06 & -0.1 & 0.4 \\
\hline HRSP & 0.3 & 0.4 & -0.3 & -0.01 & -0.05 & 0.09 & 0.2 & 0.3 & -0.8 \\
\hline Constant & $1.3^{*}$ & 1.1 & 1.1 & 0.4 & -1.3 & 1.2 & 0.4 & -0.5 & 0.8 \\
\hline Log-likelihood & -217 & -155.6 & -59.8 & -228.7 & -160.7 & -62.5 & -225.4 & 160 & -62.4 \\
\hline Likelihood ratio $\chi^{2}$ & 28.7 & 18.8 & 13.2 & 5.7 & 9.6 & 6.6 & 9.8 & 9 & 6.8 \\
\hline p-value & 0.0004 & 0.009 & 0.07 & 0.7 & 0.2 & 0.5 & 0.3 & 0.3 & 0.5 \\
\hline $\mathrm{N}$ & 337 & 240 & 97 & 337 & 240 & 97 & 337 & 240 & 97 \\
\hline
\end{tabular}

Note. ${ }^{*} \mathrm{p}<0.05, * * \mathrm{p}<0.01, * * * \mathrm{p}<0.001$.

In Table 5, logistic regression is used to see if managers' age, marital status, number and age of children, their own working hours, and the working hours of their spouses significantly affect the probability of the outcome. When looking at the first statement, "The technology prolongs the workday because it is difficult not to continue to work when the formal workday is over" (THRS1), the only significant variables for the question are the managers' own working hours (HRSm and HRSh). Men who work 50 hours a week or more are less likely to agree with the statement than other men who work less. However, this is only significant for women who work 60 hours or more.

When analyzing managers' probability of agreeing with the statement, "The technology shortens the workday because it allows me to use all dead moments to work wherever I am" (THRS2), we find that men 40 years or older (AGE) are more likely than other men to agree with this statement as well as men with at least one child less than eight years old (YOUNG).

When analyzing managers' probability of agreeing with the statement, "The technology shortens the workday because it is easier for me to work fast when I am not at the workplace" (THRS3),only two variables are significant. Married managers (MAR) are less likely to agree with this statement than unmarried or single ones. However, men with at least one child younger than eight years old (YOUNG) are more likely to agree with the statement than other men.

\subsection{Virtual Technology and Well-Being}

Table 6. Stress, exhaustion and job demand

\begin{tabular}{lllll}
\hline & ALL & MALE & FEMALE & Fisher \\
\hline STRESS & $0.36^{* * *}$ & $0.34^{* * *}$ & 0.41 & 0.211 \\
EXHWD & $0.77^{* * *}$ & $0.76^{* * *}$ & $078^{* * *}$ & 0.672 \\
JOBDEM & $0.66^{* * *}$ & $0.66^{* * *}$ & $0.67 * *$ & 0.899 \\
$\mathrm{~N}$ & 337 & 240 & 97 & \\
\hline
\end{tabular}

Note. ${ }^{*} \mathrm{p}<0.05, * * \mathrm{p}<0.01, * * * \mathrm{p}<0.001$. 
Table 6 shows that a minority, $36 \%$ of managers say they have recently experienced stress. However, $77 \%$ are mentally exhausted after the working day, and $66 \%$ say the job is mentally demanding.

In Table 7, the connection between virtual technology and the well-being of managers is analyzed. We ask: "Are those who have a positive attitude toward the technology more likely to experience well-being than others?" The coefficients in columns (1), (2), and (3) describe the probability of managers saying that they have experienced much stress lately (STRESS). The coefficients in columns (4), (5), and (6) describe the probability of managers saying that they are often or always mentally exhausted after the working day (EXHWD). Finally, the coefficients in columns (7), (8), and (9) describe the probability of managers saying that they find their job mentally demanding (JOBDEM).

The results show that men who say that virtual technology decreases their well-being because it prevents them from the feeling of being off from work (TWB2) are more likely than other men to experience stress, exhaustion, and to find their job demanding. This is not significant for women. Men who say that technology shortens the workday because it allows them to use all dead moments to work wherever they are (THRS2) are less likely than other men to be exhausted after the workday. This correlation is not significant for stress and job demands or for women. Women who say that technology makes the reconciliation of work and family life easier as it enables them to work at home or on their vacation (TFAM1) and who say that the technology shortens the workday because it is easier for them to work fast when they are not at the workplace (THRS3) are less likely than other women to be mentally exhausted. This is not significant for stress and job demands or for men.

Table 7. Logit estimate for well-being

\begin{tabular}{|c|c|c|c|c|c|c|c|c|c|}
\hline & \multicolumn{3}{|l|}{ STRESS } & \multicolumn{3}{|l|}{ EXHWD } & \multicolumn{3}{|c|}{ JOBDEM } \\
\hline & $\begin{array}{l}\text { All } \\
(1)\end{array}$ & $\begin{array}{l}\text { Male } \\
(2)\end{array}$ & $\begin{array}{l}\text { Female } \\
\text { (3) }\end{array}$ & $\begin{array}{l}\text { All } \\
(4) \\
\end{array}$ & $\begin{array}{l}\text { Male } \\
(5) \\
\end{array}$ & $\begin{array}{l}\text { Female } \\
\text { (6) }\end{array}$ & $\begin{array}{l}\text { All } \\
(7) \\
\end{array}$ & $\begin{array}{l}\text { Male } \\
(8)\end{array}$ & $\begin{array}{l}\text { Female } \\
(9)\end{array}$ \\
\hline \multicolumn{10}{|c|}{ Technology Attitude: } \\
\hline TFAM1 & 0.3 & 0.6 & -0.7 & -0.4 & -0.1 & -1.3 & 0.006 & 0.4 & $-1.9^{*}$ \\
\hline TFAM2 & 0.3 & 0.4 & 0.5 & 0.2 & 0.3 & 0.4 & 0.2 & 0.4 & -0.2 \\
\hline THRS1 & -0.5 & -0.3 & -1.1 & -0.2 & 0.02 & -0.8 & -0.4 & -0.2 & -1.1 \\
\hline THRS2 & -0.3 & -0.3 & -0.2 & $-0.9^{*}$ & $-1.1^{*}$ & -0.2 & 0.2 & -0.1 & 1.5 \\
\hline THRS3 & 0.05 & 0.08 & -0.3 & 0.2 & 0.4 & -0.6 & -0.4 & 0.06 & $-2.0^{*}$ \\
\hline TWB1 & -0.5 & -0.5 & -0.7 & -0.05 & -0.3 & 0.7 & -0.5 & $-0.9^{*}$ & 0.9 \\
\hline TWB2 & $1.1 * * *$ & $-1.6^{* * *}$ & 0.02 & $-1.2 * *$ & $-1.3 * *$ & -1.1 & $-0.8^{*}$ & $-1.2 * *$ & 0.1 \\
\hline \multicolumn{10}{|l|}{ Demography: } \\
\hline FEM & 0.6 & & & 0.09 & & & 0.3 & & \\
\hline AGE & -0.09 & -0.3 & 0.006 & $-1.5 * *$ & $-1.7^{*}$ & -1.2 & -0.5 & $-1.3^{*}$ & 0.4 \\
\hline MAR & 0.3 & 0.03 & 1.2 & -1.1 & 0.1 & -2 & 0.05 & -0.5 & 0.5 \\
\hline $\mathrm{CHI}$ & -0.08 & -0.2 & 0.06 & -0.3 & -0.3 & -0.6 & -0.4 & -0.6 & -0.1 \\
\hline YOUNG & $0.8^{*}$ & 0.5 & $1.4^{*}$ & -0.2 & -0.07 & -0.1 & 0.5 & -0.005 & 1.3 \\
\hline \multicolumn{10}{|l|}{ Hours: } \\
\hline HRSm & 0.5 & 0.1 & $1.6^{*}$ & 0.4 & 0.3 & 0.7 & $0.7^{*}$ & $0.7^{*}$ & $1.7^{*}$ \\
\hline HRSh & 0.6 & 0.3 & $1.8^{*}$ & $1.3^{* *}$ & $1.1^{*}$ & Omitted & $1.2 * * *$ & $1.6^{* * *}$ & 1 \\
\hline HRSP & -0.5 & -0.4 & -1.6 & 0.1 & 0.1 & 0.02 & -0.1 & -0.2 & -0.6 \\
\hline Constant & -0.2 & 0.5 & -0.1 & $4.8 * * *$ & $3.9^{* *}$ & $6.0 * *$ & $1.8^{*}$ & $3.3^{*}$ & 1.4 \\
\hline Log-likelihood & 194.6 & -134.8 & -53 & -160.9 & -117.3 & -38 & 195.5 & -134.5 & -48.2 \\
\hline Likelihood ratio $\chi^{2}$ & 50.9 & 37.3 & 25.5 & 45.3 & 30.8 & 16 & 40.4 & 39.3 & 26.6 \\
\hline p-value & 0.000009 & 0.0007 & 0.03 & 0.00007 & 0.006 & 0.2 & 0.0004 & 0.0003 & 0.02 \\
\hline $\mathrm{N}$ & 337 & 240 & 97 & 337 & 240 & 80 & 337 & 240 & 97 \\
\hline
\end{tabular}

Note. ${ }^{*} \mathrm{p}<0.05, * * \mathrm{p}<0.01, * * * \mathrm{p}<0.001$.

Furthermore, being younger than 40 years old lowers the probability of men being mentally exhausted often or always after the working day, but this is not significant for women. Having at least one child younger than eight years old increases the probability of women having recently experienced stress, but this is not significant for men. Also, spending more than 50 hours a week on salaried work increases the probability of women having recently experienced stress, but this is not significant for men. In contrast, spending more than 60 hours a week on salaried work increases the probability of men finding their job mentally demanding but this is not significant 
for women. However, the lack of significance for women may arise because there were fewer women in the sample.

\section{Discussion}

The managers in our data work long hours, frequently use digital technology, feel that their job demands are difficult, and often feel exhausted. In order to analyze the impact of virtual work on their work-life balance, we put forward some statements. Two of them are about the reconciliation of work and family life. The first one is: Virtual technology makes the reconciliation of work and family life easier as it enables me to work at home or on my vacation. Almost an equal number of men (81\%) and women (80\%) support the statement, showing that both genders appreciate the blurring boundaries between work and family life up to a point. Interestingly, male managers who have a partner who works 40 hours a week or more are more likely than other men to support the statement. Female managers who have young children at home are also more supportive than other women.

It is important to see the answers in the context of the gendered demographics, whereby male managers are more likely $(56 \%)$ than their female counterparts $(7 \%)$ to have a spouse who only works part-time. However, the minority of male managers who live in a double career relationship and have a spouse who works a full day or more outside the home are probably more likely than other men to go home earlier from work due to family reasons. Hence, they value the possibilities of continuing to work in the evening. In that sense, virtual technology improves the work-life balance for them. On the other hand, women with young children are most likely to have a partner who also works full-time. This can explain the gender differences in the answers and why women with young children value the blurring boundaries between work and home more than other women.

The next statement is: Virtual technology makes the reconciliation of work and family more complicated as it is more difficult to be off from work, even on vacation. Here, we refer to the discussion mentioned above (Blair-Loy, 2009; Kvande, 2007) about the difficulties of being free from work due to digital technology. Around half of the managers support the statement, but fewer women (47\%) than men (58\%) support it. Managers in relationships are more likely than single ones to disagree, but female managers working 60 hours or more are more likely than other women to support the statement. The reason might be that people in relationships are expected not to stay at their workplace late in the evenings or on weekends, making them prefer to move work from the office to their home instead. They can also stay in touch with their workmates, even during their vacations. It might be that women who work as long as 60 hours a week, and additionally are most likely to have a spouse who works as many hours as they themselves, find it difficult to continue to work when they are finally home after a long day at the office. In other words, even if they might like the possibilities of moving work to the home instead of staying at the workplace, their main responsibility for the family (Rafnsdóttir \& Heijstra, 2013; Rodriguez, 2011) might make them experience overly negative spread effects from work to the family if they continue working while at home.

The managers were asked if virtual technology prolongs or shortens the workday. The first statement was: Virtual technology prolongs the workday because it is difficult not to continue to work when the formal workday is over. The majority of managers (56\%) support the statement. However, men who work 50 hours a week or more are less likely than other men to agree with the statement. The same applies for women who work 60 hours or more. It is obvious that managers continue to work virtually after they leave their office. However, the reason why those who have the longest hours are less likely than others to support the statement may be because they see it as a change of pace not to be stuck in the office all the time. On the other hand, those who have shorter working hours are more likely to see it as an alternative to finishing the work before they go home, so any extra work in the evenings simply prolongs the workday.

The minority (45\%) of managers support the statement, Virtual technology shortens the workday because it allows me to use all dead moments to work wherever I am. This also applies to the statement: Virtual technology shortens the workday because it is easier for me to work fast when I am not at the workplace. The minority (43\%) of managers also support this statement. Married managers are less likely to support the statement than unmarried or single managers. Those who are single might have more time and peace at home for work. Interestingly, men with at least one child younger than eight years old are more likely to say the technology shortens the workday due to the above-mentioned reasons than other men. We do not know from this data if this says something about the situation in their workplace, or if it is because they get support when they work at home to continue their workday in peace and quiet. We do not see the same trend among their female counterparts.

The fact that some managers who say that virtual technology prolongs the workday also say that it improves the work-life balance is interesting. The prolonging of the workday is in line with Blair-Loy's (2009) and Kvande's 
(2007) studies. However, in contrast to their studies, the majority of Icelandic managers say the technology also increases work-life balance. If virtual technology prolongs the workday, it should probably also work against the work-family balance, which is not the case according to these results. It might be that the possibilities of going home earlier instead of spending long hours at the office, and the possibilities of being able to work flexibly when the children are in bed, are seen as most important for the work-life balance, and even more important than the total number of working hours.

We had three statements regarding virtual technology and well-being. Interestingly, those who support the statement Virtual technology increases my well-being because I can partly work from home instead of being bound to the workplace are less likely to feel mentally exhausted after the workday. However, we do not see the same correlation regarding stress and job demands. No gender difference applies in the data.

Men who experience work stress, exhaustion, and job demands are more likely than other men to support the statement Virtual technology decreases my well-being because it prevents me from actually being off from work. Thus, virtual technology is not able to increase the level of well-being among this group of men, on the contrary, they experience virtual technology as an extra burden. Our data cannot explain why this only appears for men but not for women.

The present study is not without limitations. It can be seen as a weakness that the study is based on cross-sectional data. We are only able to measure the correlation between the questions, but not the causality. In addition, the $50 \%$ response rate is lower than desired, but as this group of employees has a heavy workload, this response rate is understandable. It can be seen both positively and negatively that the statements include two issues simultaneously like: "Virtual technology makes the reconciliation of work and family life easier, as it enables me to work at home or on my vacation." Here, it was seen as important to make two statements in one sentence, as the aim was not only to measure if the managers believed the technology improved the work-life balance, but also if it was due to the above-mentioned reason.

The data was collected in a country where the government has enforced a law aiming to increase the number of women in business leadership. Therefore, it is important to understand what strengthens gender equality in top management in the context of the paper; to what extent digital technology improves or diminishes the work-life balance among women and men. Interestingly, we see some gender patterns in the responses, which could reflect the differences in the demographic. More female than male managers are single, but those who have a partner are most likely to live in a dual career family. They are younger, more likely to have one or more young children, and feel stressed. The results of the study contribute to emerging theories about digital technology, gender, and work-life balance. Nevertheless, the results are contradictory to some extent as the managers both mention that virtual technology improves the work-life balance and prolongs the workday. This may be understandable as we are partly dealing with conflicting interests, the profession and the family, which are both highly time-consuming and unpredictable at times. Therefore, we hope that our findings encourage other researchers to further study the connection between virtual technology and work-life balance, not the least among managers. By that, we might possibly prevent virtual technology from deteriorating the work-life balance and working against the above-mentioned goal of improving gender balance in business leadership.

\section{Conclusion}

It is important that human resource managers and those who are responsible for the work environment and occupational health in businesses design gender aware policies about virtual work. This could prevent an overly heavy workload and negative spread effects from work to family. This is especially important for managers and employees who work long hours.

\section{Acknowledgements}

We thank the University of Iceland Research Fund and the Icelandic Student Innovation Fund for supporting this study.

\section{References}

Blair-Loy, M. (2001). Cultural constructions of family schemes: The case of women finance executives. Gender and Society, 15(5), 687-709.

Blair-Loy, M. (2009). Work without end? Scheduling flexibility and work-to-family conflict among stockbrokers. Work and Occupations, 36(4), 279-317. http://dx.doi.org/10.1177/0730888409343912 
European Parliament. (2011). Report on women and business leadership. Retrieved September 9th 2014 from http://www.europarl.europa.eu/sides/getDoc.do?pubRef=-//EP//TEXT+REPORT+A7-2011-0210+0+DOC+ $\mathrm{XML}+\mathrm{V} 0 / / \mathrm{EN} \#$ top(2010/2115(INI)

Global Internet Users. (2012). Retrieved September 2nd 2014 from http://en.wikipedia.org/wiki/Internet_in_Europe

Heijstra, T. M., \& Rafnsdottir, G. L. (2010). The Internet and academics' workload and work-family balance. The Internet and Higher Education, 13(3), 158-163. http://dx.doi.org/10.1016/j.iheduc.2010.03.004

Heikkinen, S., Lämsä, A. M., \& Hiillos, M. (2013). Narratives by women managers about spousal support for their careers. Scandinavian Journal of Management. http://dx.doi.org/10.1016/j.scaman.2013.04.004

Huws, U. (2013). Working online, living offline: Labour in the Internet age. Work Organization, Labour \& Globalization, 7(1),1-11.

Kvande, E. (2007). Doing gender in flexible organizations. Bergen: Fagbokforlaget.

Leineweber, C., Baltzer, M., Hanson, L. L. M., \& Westerlund, H. (2012). Work-family conflict and health in Swedish working women and men: A 2-year prospective analysis (the SLOSH study). European Journal of Public Health, 23(4), 710-716. http://dx.doi.org/10.1093/eurpub/cks064

Lyon, D., \& Woodward, A. E. (2004). Gender and time at the top: Cultural constructions of times in high-level careers and homes. European Journal of Women's Studies, 11(2), 205-221. http://dx.doi.org/10.1177/1350506804042096

OECDStat. Extracts. (n.d.). Retrieved September 2nd 2014 from http://stats.oecd.org/Index.aspx?DataSetCode=LFS_SEXAGE_I_R

Rafnsdóttir, G. L. (2011). Lack of gender diversity in business leadership. Potential barriers and solutions - case of the Nordic countries. In Rašticová, M. (Ed.), Diversity is Reality (pp. 97-105). Brno: Vutium Press.

Rafnsdóttir, G. L., \& Heijstra, T. M. (2013). Balancingwork-familylife in academia: Thepower of time. Gender, Work \& Organization, 20(3), 283-296. http://dx.doi.org/10.1111/j.1468-0432.2011.00571.x

Rafnsdóttir, G. L., Einarsdóttir, T., \& Snorrason, J. S. (2014). Gender diversity on boards in organizations. In DeVos, M., \& Culliford, P. (Eds.), Gender quota for the Board of Directors (pp. 147-157). Cambridge: Intersentia.

Rodriguez, J. K. (2011). Joining the dark side: Women in management in the Dominican Republic. Gender, Work and Organization. Retrieved July 21st 2014 from http://onlinelibrary.wiley.com/doi/10.1111/j.1468-0432.2010.00541.x/pdf.

Snaebjornsson, I. M., \& Edvardsson, I. R. (2013). Gender, Nationality and Leadership Style: A Literature Review. International Journal of Business and Management, 8(1), 89-103. http://dx.doi.org/10.5539/ijbm.v8n1p89

Statistic Iceland. (2012). Information and communication technologies in enterprises. Statistical Series. Tourism, transport and IT. Retrieved September 12th 2014 a from http://www.statice.is/lisalib/getfile.aspx?ItemID=14254

Statistic Iceland. (n.d). Media and culture. Retrieved September 12th 2014 a from http://www.statice.is/Statistics/Culture

The Global Gender Gap Report. (2013). Geneva: World Economic Forum.

Wajcman, J. (2004). Techno Feminism. Cambridge: Polity Press.

\section{Notes}

Note 1. See European Commission, Proposal for a Directive of the European Parliament and of the Council on improving the gender balance among non-executive directors of companies listed on stock exchanges and related measures, 2012/0299 (COD), Nov. 14, 2012, art. 4.

Note 2. In this article, we use the term "virtual work" when referring to labor carried out using a combination of digital and telecommunications technologies and/or that produces content for digital media (COST Action IS 1202 - The Dynamics of Virtual Work. Ursula Huws). 


\section{Copyrights}

Copyright for this articleis retained by the author(s), with first publication rights granted to the journal.

This is an open-access article distributed under the terms and conditions of the CreativeCommons Attribution license (http://creativecommons.org/licenses/by/3.0/). 